\title{
Роль буферной емкости в системе идентификации разбавления вин водой
}

\author{
Виктория Григорьевна Гержикова, д-р техн. наук, проф., гл. науч. сотр. лаборатории химии и биохимии вина, hv26@mail.ru; \\ Надежда Станиславовна Аникина, д-р техн. наук, начальник лаборатории химии и биохимии вина, hv26@mail.ru, \\ https://orcid.org/0000-0001-5282-3426;
}

Дмитрий Юрьевич Погорелов, науч. сотр. лаборатории химии и биохимии вина, pogdmi@ro.ru, http://orcid.org/00000001-6388-9706;

Марианна Вадимовна Ермихина, науч.сотр. лаборатории химии и биохимии вина, mariannaermikhina@mail.ru; Лилия Анатольевна Михеева, мл. науч .сотр. лаборатории химии и биохимии вина, lili_mih@ro.ru; Антонина Валерьевна Весютова, канд .техн. наук, науч. сотр. лаборатории химии и биохимии вина, foxt.80@mail.ru; Ольга Викторовна Рябинина, мл. науч. сотр. лаборатории химии и биохимии вина, olgar@list.ru, https://orcid.org/00000002-5078-4515

Федеральное государственное бюджетное учреждение науки «Всероссийский национальный научно-исследовательский институт виноградарства и виноделия «Магарач» РАН», Россия, Республика Крым, 298600, г. Ялта, ул. Кирова, 31

Результаты исследований последних лет показывают, что внесение воды в сусло или вино нарушает баланс ионов, изменяет значения физико-химических, органолептических и интегральных показателей. Одним из наиболее важных показателей, позволяющих установить добавку воды, является буферная емкость вина (БЕ). Буферная емкость вина представляет собой его способность противостоять изменениям $\mathrm{pH}$ после добавления сильной кислоты или основания. Сила кислоты характеризуется константой диссоциации. Её отрицательный логарифм $\mathrm{pKa}$ означает значение $\mathrm{pH}$, при котором соотношение недиссоциированной и диссоциированной по I ступени форм кислоты составляет 1:1. Нами модифицирован метод определения буферной емкости, основанный на результатах ацидиметрического (БЕк) и алкалиметричеСкого (БЕщ) титрования вина, с помощью которого можно оценить степень диссоциации органических кислот, соотношение их молекулярных и ионизированных форм, состояние ионов металлов, способность регулировать скорость химических реакций окисления и восстановления. В работе были использованы подлинные сухие белые и красные виноматериалы, полученные в условиях микровиноделия и производства в сезоны виноделия 2017-2018 гг. из винограда сортов Алиготе, Шардоне, Совиньон зеленый, Кокур белый, Каберне-Совиньон, Мерло, Санджовезе. Для изучения влияния разбавления виноматериалов водопроводной водой проводили ее добавку в количестве 10-70 \%. Объем выборки составил 131 образец. Разбавление вина водой - это смешивание двух систем, одна из которых (вино) представляет собой раствор, содержащий органические кислоты и их кислые соли, обладающий $\mathrm{pH}$ и буферностью. Вода содержит соли жесткости, обусловливающие ее $\mathrm{pH}$, но не обладает буферностью, соизмеримой по величине с той, которая встречается в винопродукции. Изучены некоторые характеристики смеси вина и воды: значение соотношений кислотной и щелочной составляющих буферной емкости, при которых буферные свойства системы меняют свой характер, что соответствует 70 \% разбавлению; описаны математические модели процесса внесения воды в вино, позволяющие определить значения в любой точке разбавления, в том числе в контроле. Систематизация всей выборки позволила разделить образцы на два кластера, детерминирующие подлинные и разбавленные вина по показателю буферных свойств (ПБС), установлены значения показателя буферных свойств системы для подлинных (50-80) и разбавленных (80-100) вин.

Ключевые слова: показатель буферных свойств вина; столовые белые и красные виноматериалы и вина; pH; катионы; анионы; ацидиметрическое титрование; алкалиметрическое титрование.

\section{O R I G I N A L A R T I C L E \\ The role of buffering capacity in identification of wine dilution with water}

Viktoriya Grigoryevna Gerzhikova, Nadezhda Stanislavovna Anikina, Dmitry Yurievich Pogorelov, Marianna Vadimovna Ermikhina, Lilia Anatolyevna Mikheyeva, Antonina Valerievna Vesyutova, Olga Viktorovna Riabinina Federal State Budget Scientific Institution All-Russian National Research Institute of Viticulture and Winemaking Magarach of RAS, 31 Kirova Street, 298600 Yalta, Republic of Crimea, Russia

Studies of recent years demonstrate that introduction of water into must or wine upsets the balance of ions, changes the values of physico-chemical, organoleptic and integral indicators. One of the most important indicators to establish the addition of water is the buffering capacity of wine (BC). Buffering capacity of wine is its ability to resist changes in $\mathrm{pH}$ after addition of a strong acid or base. Acid strength is characterized by dissociation constant. Its negative pKa logarithm means $\mathrm{pH}$ value at which the non-dissociated and dissociated by stage I acid forms ratio is $1: 1$. We have modified the method for buffer capacity determination based on acidimetric and alkalimetric wine titration results, which can be used to assess organic acids dissociation degree, the ratio between their molecular and ionized forms, the state of metal ions, the ability to control the chemical oxidation reactions and recovery rate. In our work we used genuine dry white and red base wines obtained in conditions of micro-winemaking and production during the wine-making seasons of 2017-2018 from grapevine cultivars 'Aligote', 'Chardonnay', 'Sauvignon verde', 'Kokur Belyi', 'Cabernet Sauvignon', 'Merlot', 'Sangiovese'. To study the effect of base wines dilution with tap water, it was added in the amount of $10-70 \%$. The sample size made 131 samples. Dilution of wine with water is the mixing of two systems, one of which (wine) is a solution containing organic acids and their acid salts, possessing a $\mathrm{pH}$ and buffering capacity. Water contains hardness salts that determine its $\mathrm{pH}$, but does not possess buffering capacity comparable in quantity to that found in wine products. Certain characteristics of wine-water mixture were studied: the ratio between the acidic and alkaline components of the buffering capacity at which the buffering properties of the system change their natu re, which corresponds to $70 \%$ dilution; mathematical models of the process of water introduction into wine were described, allowing to determine the values at any point of dilution, including the control. The entire sample systematization allowed dividing samples into two clusters, determining genuine and diluted wines by buffering property index (PBI); the system buffering property values for genuine (50-80) and diluted (80-100) wines were established.

Key words: wine buffering property indicator; table white and red base wines and wines; pH; cations; anions; acidimetric titration; alkalimetric titration.

\section{Как цитировать эту статью:}

Гержикова В.Г., Аникина Н.С., Погорелов Д.Ю., Ермихина М.В., Михеева Л.А., Весютова А.В., Рябинина О.В. Роль буферной емкости в системе идентификации разбавления вин водой // «Магарач». Виноградарство и виноделие, 2019; 21(2). С.153-157. DOI 10.35547/IM.2019.21.2.015

\section{How to cite this article:}

Gerzhikova V.G., Anikina N.S., Pogorelov D.Yu., Ermikhina M.V., Mikheyeva L.A., Vesyutova A.V., Riabinina O.V. The role of buffering capacity in identification of wine dilution with water. Magarach. Viticulture and Winemaking, 2019; 21(2). pp. 153-157. DOI 10.35547/IM.2019.21.2.015

УДК 663.221/.222:54-45/.061:543.241/.257

Поступила 14.05.2019

Принята к публикации 16.05.2019

(САвторы, 2019 
И нтеграционные процессы, проходящие в экономике Российской Федерации, выдвигают более жесткие требования к контролю качества и безопасности винодельческой продукции. Недобросовестные производители применяют запрещенные добавки и приемы, которые представцяют угрозу экономическим интересам страны. МежАународная организации винограда и вина (МOBB) ввоАит нормы Аля ряда компонентов, связанные с качеством и безопасностью вин, преАставленные в «Компендиуме международных методов анациза сусла и вина», который является основой научной, правовой и практической деятельности в виноделии [1].

ОАНИМ ИЗ СПОСОбов ПОААЕАКИ ВИНОПРОАУКЦИИ ЯВАЯется разбавление виноматериалов водой [2]. Результаты исследований последних мет свидетельствуют о том, что внесение воды в сусло ими вино нарушает баланс катионов и анионов, изменяет значение физико-химических, органолептических и интегральных показатемей [3-5]. ОАним из показателей описания физико-химического состава винопродукции является буферная емкость, зависящая от степени диссоциации органических кислот, соотношения их молекулярных и ионизированных форм, состояния ионов метамлов и вцияющая на способность вина сопротивцяться сАвигу $\mathrm{pH}$, технологическое Аействие Аиоксида серы и сорбиновой кислоты при обработке, регулировку скорости химических реакций окисления и восстановления [6].

Буферной емкостью характеризуются вина, способные противостоять изменениям значению $\mathrm{pH}$ после добавления симьной кислоты или основания. Основными буферными соединениями в вине явмяются органические кислоты и их кислые соли. Вино с большим значением буферности характеризуется и более высоким их содержанием $[6,7]$. В современной отечественной и зарубежной митературе разделяют термины «сумма кислот» и «титруемая кислотность», первый из которых относится к количеству неАиссоциированных и диссоциированных форм органических кислот вина, которое может быть определено путем оценки и математического суммирования результатов, полученных с использованием методов ВЭЖХ $[8,9]$. Титруемая кислотность, как правило, представмена суммой свободных протонов и кислотных групп недиссоциированных органических кислот, которые могут быть оттитрованы щелочью, то есть $[\mathrm{H}]^{+}$и $[\mathrm{COOH}]^{-}$. Практика опредемения содержания титруемых кислот основана на реакции нейтрацизации вина щелочью до значения рН 7,0 (ЕЭС) и $\mathrm{pH}$ 8,2 (США). Водородный показатель $\mathrm{pH}$ преАставмяет собой отрицатемьный десятичный могарифм концентрации катионов водорода, которые образуются при Аиссоциации неорганических и органических кислот, а также их кисАых солей [10].

О симе кислоты по отношению к Аругим кислотам суАят по константе Аиссоциации. Её отрицательный цогарифм обозначают рКа. Амя Авухосновных органических кислот $\mathrm{pKa} \mathrm{Аиссоциации} \mathrm{-} \mathrm{значение} \mathrm{pH}$, при котором соотношение недиссоциированной и Аиссоциированной по I ступени ее формы составцяет $1: 1$. Неорганические кислоты (соляная, серная) являются сильными электролитами и Аиссоциируют в вине полностью [11].
Оригинальное исследование проведено ObrequeSlier E. et al. [12]. Авторами было доказано, что во время дегустации вино взаимодействует со слюной полости рта, значение $\mathrm{pH}$ которой составцяет около 7. Буферная система слюны представлена парой карбонат/ бикарбонат $(\mathrm{pKa}=6,1)$. Бымо установлено, что аликвота вина $\left(0,27 \mathrm{~cm}^{3}\right)$ в полости рта приводит к снижению $\mathrm{pH}$ слюны, однако во время Аегустации суммарная кисмотность среаы соответствует $\mathrm{pH}$ вина. Значение $\mathrm{pH}$ может проявцяться в изменении степени диссоциации органических кислот и их кислых солей, зависит от вемичины буферной емкости и эмектропроводности.

Некоторые компоненты вин обладают незначительными буферными характеристиками, но могут оказывать влияние на них при добавлении в вина. Бымо установцено, что взаимодействие танинов с протеинами и внесение некоторых полифенолов позволяют усиливать действие буферной системы винная кисмота - битартрат калия [13-15]. Изменение буферных свойств системы вина может быть связано с некоторыми компонентами вина, в частности, с полифенолами и аминокислотами [16-19].

В связи со сказанным целью настоящей работы была оценка роли $\mathrm{pH}$ и буферной емкости в системе идентификации разбавления вин водопроводной водой.

\section{Методика проведения работы}

В работе были использованы подиинные сухие бе$\Lambda$ ие и красные виноматериалы, полученные в условиях микровиноделия и производства в сезоны виноделия 2017-2018 гг. из винограда сортов А^иготе, Шардоне, Совиньон белый, Кокур белый, Каберне-Совиньон, Мерло, Санджовезе и ар. (Крым, с. Угловое, с. Ромашино, с. Морское, пгт. Гурзуф) по кмассическим технологиям с использованием чистой культуры дрожжей 47-К из колмекции микроорганизмов ФГБУН «ВННИИВиВ «Магарач» $\mathrm{PAH»} \mathrm{(г.} \mathrm{Я \Lambda та).}$

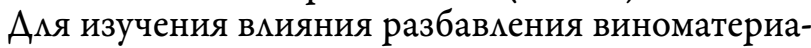

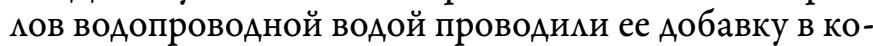

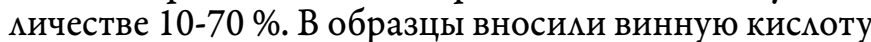
в дозе 1-2 г/Ам³. В работе использовали необработанные виноматериалы. ПереА работой виноматериал отфильтровывали через бумажный фильтр и определяли значения следующих показателей: $\mathrm{pH}$, БЕк (ацидиметрическое титрование), БЕщ (алкалиметрическое титрование) исходного образца, ПБС, а также изменение их значений в ходе измерения.

Исследования проводили предложенным нами методом, основанным на измерении количества стандартного раствора $1 \mathrm{M} \mathrm{NaOH}$ или $\mathrm{HCl}$, необходимого Аля смещения активной кислотности пробы вина $(\mathrm{pH})$ на еАиницу в сторону ее повышения (щелочная составляющая буферной емкости) ими понижения (кислотная составмяющая буферной емкости) [3, 9], и расчете показателя буферных свойств вина (ПБС):

$$
\text { ПБС }=\frac{\text { БЕК }}{\text { БЕщ }} \times 100,
$$

гАе БЕк - кислотная составляющая буферной емкости, ммоль-экв/ АM $^{3}$; БЕщ - щелочная составцяющая буферной емкости, ммоль-экв/Ам'

Результаты измерений обрабатывали методами математического анамиза с помощью пакета прикцаАных программ MS Excel Offise (Windows). Объем вы- 
Таблица. Результаты щелочного и кислотного титрования образцов

Table. Alkaline and acid titration of samples data

\begin{tabular}{|c|c|c|c|c|c|c|c|c|c|}
\hline \multirow{2}{*}{ Образец } & \multicolumn{4}{|c|}{ Титрование щемочью } & \multicolumn{4}{|c|}{ Титрование кислотой } & \multirow{2}{*}{ ПБС } \\
\hline & $\mathrm{pH}_{1}$ & $\mathrm{pH}_{2}$ & $V^{*}, A^{3}$ & БЕщ, ммоль-экв/Ам ${ }^{3}$ & $\mathrm{pH}_{1}$ & $\mathrm{pH}_{2}$ & $\mathrm{~V}, \mathrm{AM}^{3}$ & БЕк, ммо ь-экв/АМ ${ }^{3}$ & \\
\hline \multicolumn{10}{|c|}{ Anuгоmе 1} \\
\hline Контромь & 3,251 & 4,261 & 1,95 & 39,0 & 3,256 & 2,234 & 1,25 & 25,0 & 64,1 \\
\hline Опыт 1 & 3,193 & 4,199 & 1,54 & 30,8 & 3,197 & 2,198 & 1,20 & 24,0 & 77,9 \\
\hline Опыт 2 & 3,048 & 4,044 & 1,80 & 36,0 & 3,049 & 2,039 & 1,28 & 25,6 & 71,1 \\
\hline Опыт 3 & 2,941 & 3,950 & 2,10 & 42,0 & 2,941 & 1,938 & 1,48 & 29,6 & 70,5 \\
\hline Опыт 4 & 3,203 & 4,197 & 1,00 & 20,0 & 3,206 & 2,204 & 0,95 & 19,0 & 95,0 \\
\hline Опыт 5 & 2,981 & 3,998 & 1,28 & 25,6 & 2,980 & 1,983 & 1,10 & 22,0 & 85,9 \\
\hline Опыт 6 & 2,834 & 3,84 & 1,51 & 30,2 & 2,832 & 1,835 & 1,45 & 29,0 & 96,0 \\
\hline \multicolumn{10}{|c|}{ Aлиготе 2} \\
\hline Контромь & 2,921 & 3,921 & 2,50 & 50,0 & 2,927 & 1,920 & 1,66 & 33,2 & 66,4 \\
\hline Опыт 1 & 2,898 & 3,902 & 1,96 & 39,2 & 2,901 & 1,898 & 1,46 & 29,2 & 74,5 \\
\hline Опыт 2 & 2,819 & 3,823 & 2,34 & 46,8 & 2,818 & 1,817 & 1,67 & 33,4 & 71,4 \\
\hline Опыт 3 & 2,743 & 3,744 & 2,50 & 50,0 & 2,745 & 1,740 & 1,80 & 36,0 & 72,0 \\
\hline Опыт 4 & 2,908 & 3,910 & 1,26 & 25,2 & 2,909 & 1,902 & 1,20 & 24,0 & 95,2 \\
\hline Опыт 5 & 2,774 & 3,780 & 1,51 & 30,2 & 2,770 & 1,773 & 1,46 & 29,2 & 96,7 \\
\hline Опыт 6 & 2,702 & 3,704 & 1,85 & 37,0 & 2,696 & 1,699 & 1,65 & 33,0 & 89,2 \\
\hline \multicolumn{10}{|c|}{ Мерло } \\
\hline Контромь & 3,681 & 4,693 & 1,90 & 38,0 & 3,675 & 2,669 & 1,55 & 31,0 & 81,6 \\
\hline Опыт 1 & 3,640 & 4,661 & 1,60 & 32,0 & 3,646 & 2,658 & 1,30 & 26,0 & 81,3 \\
\hline Опыт 2 & 3,448 & 4,452 & 1,95 & 39,0 & 3,437 & 2,434 & 1,45 & 29,0 & 74,4 \\
\hline Опыт 3 & 3,289 & 4,294 & 2,25 & 45,0 & 3,287 & 2,280 & 1,65 & 33,0 & 73,3 \\
\hline Опыт 4 & 3,636 & 4,643 & 1,00 & 20,0 & 3,637 & 2,628 & 0,85 & 17,0 & 85,0 \\
\hline Опыт 5 & 3,290 & 4,288 & 1,30 & 26,0 & 3,291 & 2,293 & 1,10 & 22,0 & 84,6 \\
\hline Опыт 6 & 3,130 & 4,126 & 1,58 & 31,6 & 3,129 & 2,123 & 1,35 & 27,0 & 85,4 \\
\hline \multicolumn{10}{|c|}{ Каберне-Совиньон } \\
\hline Контромь & 3,546 & 4,542 & 2,01 & 40,2 & 3,538 & 2,529 & 1,59 & 31,8 & 79,1 \\
\hline Опыт 1 & 3,495 & 4,491 & 1,63 & 32,6 & 3,503 & 2,501 & 1,30 & 26,0 & 79,8 \\
\hline Опыт 2 & 3,315 & 4,316 & 1,91 & 38,2 & 3,324 & 2,320 & 1,50 & 30,0 & 78,5 \\
\hline Опыт 3 & 3,172 & 4,181 & 2,21 & 44,2 & 3,202 & 2,196 & 1,66 & 33,2 & 75,1 \\
\hline Опыт 4 & 3,457 & 4,472 & 1,02 & 20,4 & 3,465 & 2,458 & 0,95 & 19,0 & 93,1 \\
\hline Опыт 5 & 3,250 & 4,252 & 1,33 & 26,6 & 3,194 & 2,190 & 1,20 & 24,0 & 90,2 \\
\hline Опыт 6 & 3,068 & 4,065 & 1,65 & 33,0 & 3,068 & 2,059 & 1,43 & 28,6 & 86,7 \\
\hline
\end{tabular}

Примечание: $\mathrm{V}^{*}$ - объем титранта, пошедшего на титрование; Опыт 1 - разбавление водой на $20 \%$; Опыт 2 - разбавление водой на $20 \%+1$ г/ Ам $^{3}$ винной кислоты; Опыт 3 - разбавмение водой на $20 \%+2$ г/Ам³ винной кислоты; Опыт 4 - разбавление водой на 50 \%; Опыт 5 - разбавление водой на $50 \%+1$ г/Ам³ винной кислоты; Опыт 6 - разбавление водой на $50 \%+2$ г/Ам винной кислоты; $\mathrm{pH}_{1}-$ активная кислотность исходного образца; $\mathrm{pH}_{2}$ - активная кислотность после титрования; БЕщ - щелочная составмяющая буферной

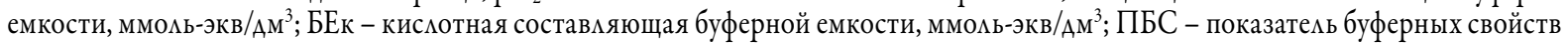

борки составим 131 образец.

\section{Результаты и обсуждение}

Буферная емкость образцов определяется исходной величиной $\mathrm{pH}_{1}($ табц.). В белых столовых виноматериалах, полученных из одного сорта виноградас разным $\mathrm{pH}_{1}$ (Алиготе 1) и (Алиготе 2), значения щелочной и кислотной составляющих БЕ равняются 39,0 и 25,0 мМОАь-эКв $/ \mathrm{AM}^{3}$ и 50,0 и 33,2 ммо ь-эКв/ $/ \mathrm{AM}^{3}$ соответственно. Разбавление виноматериалов водой на $20 \%$ (опыт 1) снижает исходные значения БЕщ и БЕк образца Алиготе 1 на 8,2 и 1,0 ммоль-экв/Ам ${ }^{3}$ соответственно, а Алиготе 2 - на 10,8 и 4,0 ммоль-экв/ Ам $^{3}$. Увеличение АОАи вносимой воАы Ао $50 \%$ (опыт 4) приводит к снижению значения буферной емкости в образце Алиготе 1 на 19,0 и 6,0 ммомь-экв/Ам³ те 2 - на 24,8 и 9,2 ммоль-экв/ $\mathrm{AM}^{3}$.

Отмеченная разница в значениях БЕщ и БЕк свиАетельствует о значительном снижении буферных свойств системы вина при ее разбавлении водой (рис. 1). Прямые разведения сходятся в одной точке, соответствующей $70 \%$ доле внесенной воды, которая означает Аеформацию буферных свойств системы. Установленная взаимосвязь описывается кинейными уравнениями регрессии $\left(\mathrm{R}^{2}=0,99\right)$ :

БЕщ $=-3,95 \mathrm{w}+45,27 ;$

$\mathrm{БEK}=-1,32 \mathrm{w}+24,05$,

гАе ш - АОля внесенной воды, $\%$.

На основании полученных данных нами предложен способ, позволяющий определить исходную вемичину показатемя буферных свойств виноматериала ими вина. При анализе испытуемого образца произвоАят его разведение водой на 10-70 \%, измеряют БЕщ и БЕк, полученные значения наносят на график, соеАиняют их прямой, которую продлевают Ао пересечения с осью орАинат. Отрезки, отсекаемые по оси ординат, явАяются исходнЫми значениями показателей БЕщ и 
БЕк, которые используют Аля расчета эмпирического ПБС пробы. В поАлинных винах разница межАу эмпирическим и фактическим значениями ПБС не превышает $10 \%$.

Оценивая вмияние разбавцения вин водой, слеАует отметить, что смешиванию подвергаются Аве системы, обладающие различным составом и свойствами. Вино преАставмяет собой буферную систему, состоящую в основном из органических кислот и их кислых солей, способных к Аиссоциации и защите своего рН от изменений. Вода содержит соли жесткости, в основном кацьция и магния, обусловмивающие значение $\mathrm{pH}$ среды, но не характеризующиеся выраженным буферным Аействием. После Аобавцения воды в виноматериал значение $\mathrm{pH}$ полученной смеси немного снижается, что свидете ьствует о защитном Аействии буферной системы вина на значения собственного $\mathrm{pH}$.

Аля компенсации изменения буферных свойств разбав енных образцов было осуществлено внесение в них винной кислоты в количестве 1 и 2 г/Ам ${ }^{3}$. Помученные резумьтаты показали, что при разбавлении бемых столовых виноматериалов на $20 \%$ компенсация щелочной и кислотной составмяющих буферной емкости возможна при внесении 2 г/Ам 3 винной кислоты. При разбавлении образцов на 50 \% компенсация буферных свойств вина путем поАкисления винной кислотой невозможна. Аналогичные результаты получены и Аля выборки красных виноматериалов, отмичие которых заключается в более высоких значениях $\mathrm{pH}$.

В результате регрессионного анациза экспериментального массива данных быма установцена математическая взаимосвязь межАу показатемем ПБС, подкисмением (С) и степенью разбавления (Р) пробы водой (рис. 2):

ПБС $=77,66-2,88 \mathrm{C}+0,19 \mathrm{P}$ (Аля красных стомовых виноматериалов, $\left.\mathrm{R}^{2}=0,8\right)$,

ПБС $=63,95-2,74 \mathrm{C}+0,64 \mathrm{P}$ (Аия белых столовых виноматериалов, $\left.\mathrm{R}^{2}=0,9\right)$.

Согласно полученным результатам, разбавление образцов виноматериалов водой приводицо к увеАичению показателя ПБС, а внесение винной кисмоты - к его уменьшению $[3,6]$. Отмичие установменных закономерностей А я белых и красных виноматериалов можно объяснить нацичием в составе последних более высокого содержания веществ фенольной природы (процианиАинов, антоцианов и их олигомеров), имеющих слабую селективность к титрантам в условиях определения показателя ПБС и способных влиять на результат анациза $[15,16]$.

Систематизация экспериментальных Аанных (рис. 3) позволима выделить Ава кластера: I подиинные образцы, II - фамьсификаты (разбавленные водой). Установлено, что значения показателя буферных свойств системы ПБС подАинных вин варьируют от 50 Ао 80, а разбавленных - от 80 до 100.

Выводы. Таким образом, проведенные исследования показали, что значение соотношений кислотной и щелочной составляющих буферной емкости, при которых буферные свойства системы меняют свой характер, как правимо наступает при 70 \% разбав-

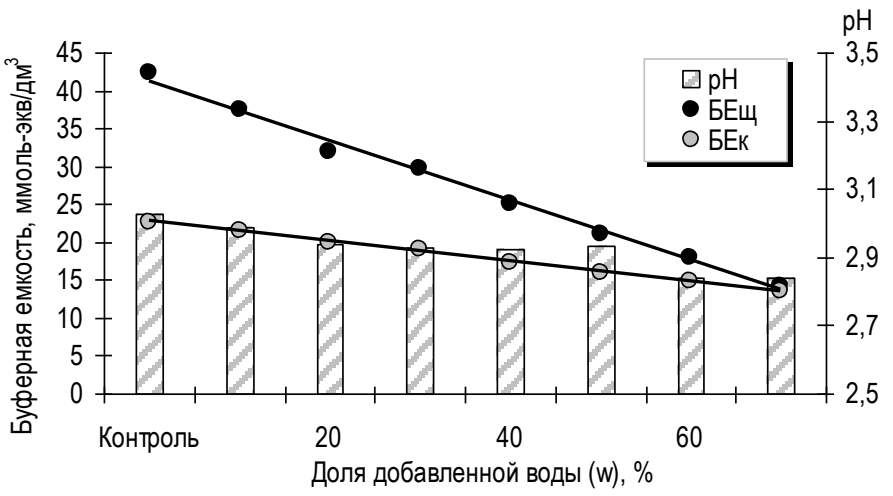

Рис. 1. Влияние разбавления водой столового виноматериала Каберне-Совиньон на значения показателей буферной емкости

Fig. 1. The effect of 'Cabernet Sauvignon' table base wine dilution with water on buffering capacity indicator values
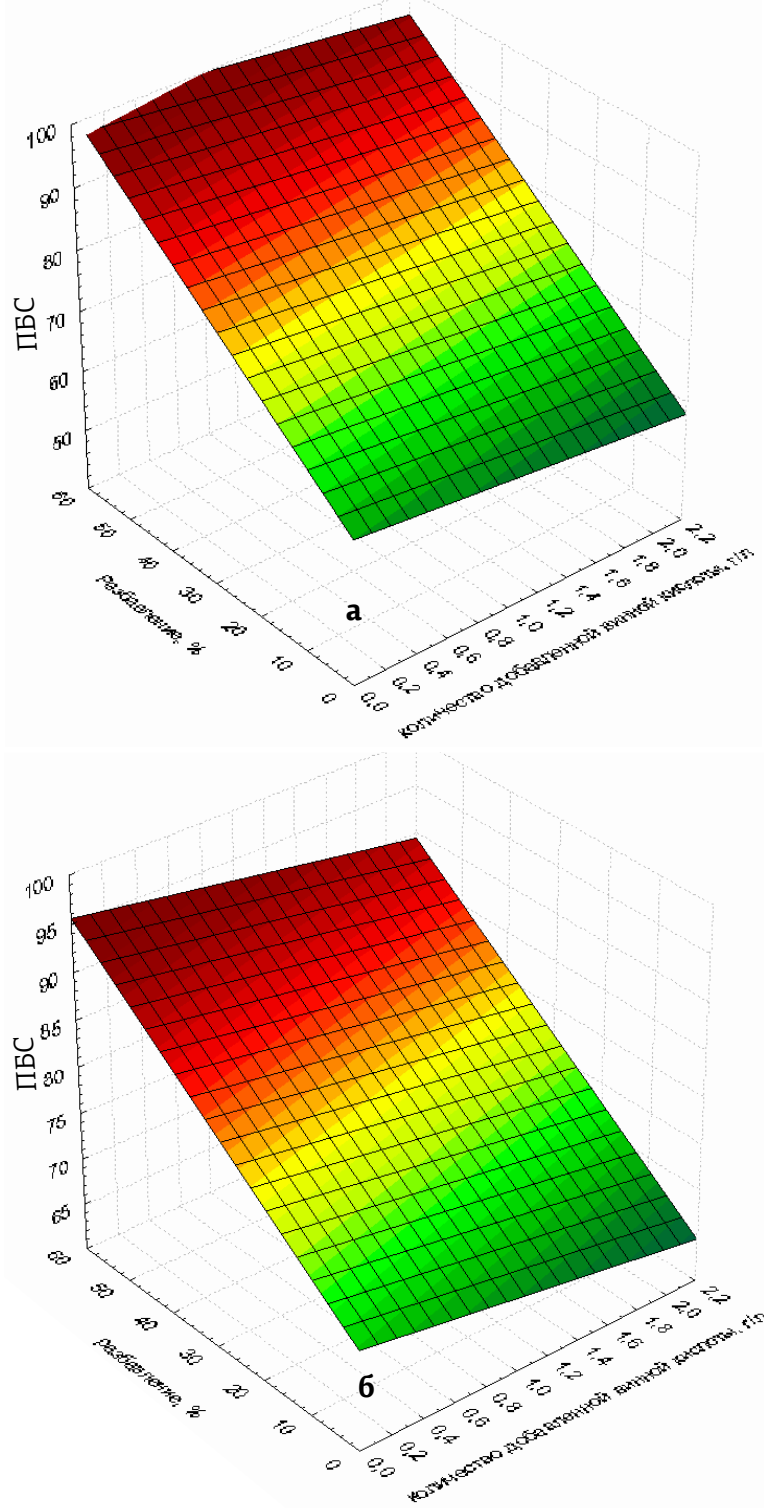

Рис. 2. Влияние разбавления виноматериалов водой $(\mathrm{P})$ и подкисления (С) на значения ПБС: а - белые столовые виноматериалы, 6 - красные столовые виноматериалы

Fig. 2. The effect of base wines dilution with water $(\mathrm{P})$ and acidification $(\mathrm{C})$ on PBI values: a - white table base wines, $\mathrm{b}$ - red table base wines

цении образца водой; описаны математические модели процесса внесения воды в вино, позволяющие опреде-

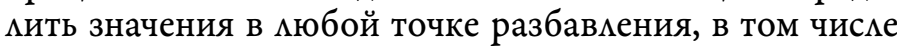



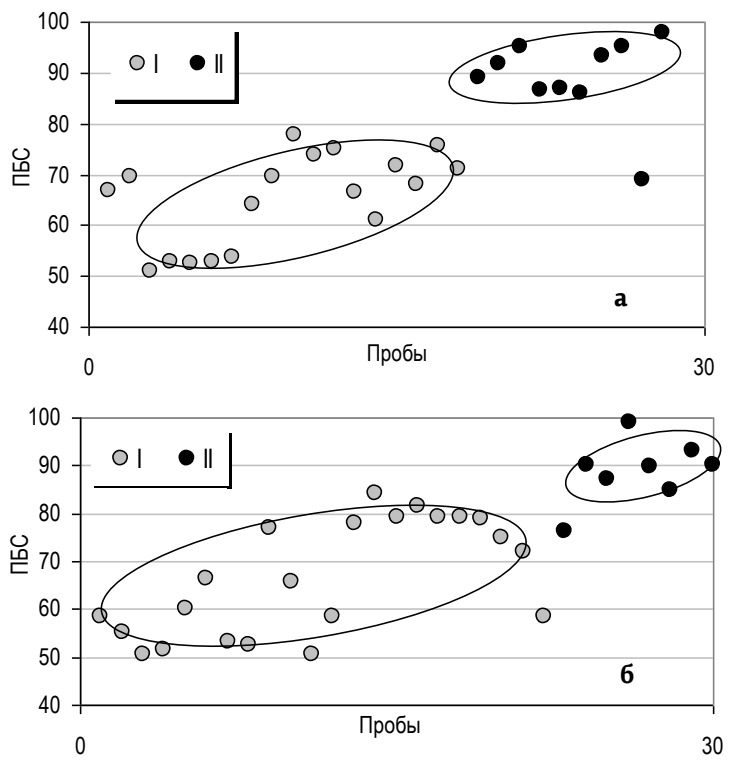

Рис. 3. Варьирование показателя ПБС для выборки столовых виноматериалов из белых (а) и красных (б) сортов винограда: I - подлинные образцы II фальсификаты, полученные разбавлением водой

Fig. 3. PBI value variation for sampling table base wines from white (a) and red (b) grapevine cultivars: I - authentic samples II - adulterated, obtained by dilution with water

в контроле. Систематизация всей выборки позволима разАелить образцы на Ава киастера, Аетерминирующие подминные и разбавленные вина по показателю буферных свойств (ПБС), установмены значения показатемя буферных свойств системы Аһя поАһинных (50-80) и разбавленных (80-100) вин.

\section{Источник финансирования}

Работа выпомнена в рамках Государственного задания № 0833-2019-0024.

\section{Financing source}

The study was conducted under public assignment № 0833-2019-0024.

\section{Конфликт интересов} Не заявцен.

\section{Conflict of inter ests} No declared.

\section{Список литературы/Reference}

1. Compendium of International Methods of Wine and Must Analysis//OIV Paris 2016 V.2 [электронный ресурс] Режим доступа: www.oiv.int/public/medias/4005/compedium. 2016. Vol.2. pdf (дата обращения: 15.03.2016).

2. Kamiloglu S. Authenticity and traceability in beverages // Food Chemistry, 2019. № 277. pp. 12-24. http://doi.org/10.1016/j. foodchem.2018.10.091.

3. Аникина Н.С., Гержикова В.Г., Гниломедова Н.В., Погорелов Д.Ю. Методология идентификации подлинности вин // Симферополь: ДИАЙ ПИ, 2017. 152 с.

Anikina N., Gerzhikova V., Gnilomedova N., Pogorelov D. Metodologiya identifikatsii podlinnosti vin [Wine Authentication Methodology]. Simpheropol: DIAI PI, 2017. 152 p. (in Russian)

4. Шелудько О.Н., Гугучкина Т.И., Стрижов Н.К. Интегральный подход к оценке качества винодельческой продукции // Виноделие и виноградарство. - 2014. № 6. С. 17-22.

Shelud'ko O.N., Guguchkina T.I., Strizhov N.K. Integral'nyj podhod $k$ ocenke kachestva vinodel'cheskoj produkcii // Vinodelie i vinogradarstvo. - 2014. № 6. pp. 17-22. (in Russian)
5. Гугучкина Т.И., Марковский М.Г., Антоненко М.В., Резниченко К.В., Бурцев Б.В. , Абакумова А.А. / Методы контроля качества и безопасности винодельческой продукции: методические рекомендации. Краснодар: ФГБУН СКФНЦСВВ, 2018. 59 c.

Guguchkina T.I., Markovskij M.G., Antonenko M.V., Reznichenko K.V., Burcev B.V., Abakumova A.A. / Metody kontrolya kachestva i bezopasnosti vinodel'cheskoj produkcii: metodicheskie rekomendacii. Krasnodar: FGBUN SKFNCSVV, 2018. 59 p. (in Russian)

6. Гержикова В.Г., Червяк С.Н., Аникина Н.С. и др. К вопросу о выявлении добавок воды в столовых виноматериалах. // «Магарач». Виноградарство и виноделие. 2018. № 2. С. $44-46$.

Gerzhikova V., Cherviak S., Anikina N. K voprosu o vyyavlenii dobavok vody v stolovykh vinomaterialakh [On the issue of identifying water additives in table wine materials] / "Magarach". Vinogradarstvo $i$ vinodelie. [Magarach. Viticulture and Winemaking]. 2018. № 2. pp. 44-46. (in Russian)

7. Аникина Н.С., Жилякова Т.А., Михеева Л.А. и др. Изучение буферной системы подлинных виноградных виноматериалов и вин // «Магарач». Виноградарство и виноделие. 2015. № 1. С. 31-33.

Anikina N., Zhilyakova T., Mikheieva L. et al. Izucheniye bufernoy sistemy podlinnykh vinogradnykh vinomaterialov $i$ vin [Study of the Buffer System of Genuine Grape Wine Materials and Wines] // «Magarach». Vinogradarstvo i vinodelie. [Magarach. Viticulture and Winemaking]. 2015. № 1. pp. 31-33. (in Russian)

8. Методы технохимического контроля в виноделии / Под ред. В.Г. Гержиковой. Симферополь: Таврида, 2009. 304 c.

Metody tekbnokbimicheskogo kontrolya v vinodelii [Techno-chemical control methods in winemaking] / Ed. by V. Gerzhikova. Simpheropol: Tavrida, 2009. 304 p. (in Russian)

9. Гержикова В.Г., Погорелов Д.Ю., Ермихина М.В., Михеева Л.А. Модификация метода определения буферной емкости столовых виноматериалов // «Магарач». Виноградарство и виноделие. 2018. № 1. С. 44-46.

Gerzhikova V., Pogorelov D., Ermikhina M., Mikheieva L. Modifikatsiya metoda opredeleniya bufernoy yemkosti stolovykb vinomaterialov [Modification of the method for determining the buffer capacity of table wine materials] // "Magarach». Vinogradarstio $i$ vinodelie. [Magarach. Viticulture and Winemaking]. 2018. № 1. P. $44-46$ (in Russian).

10. Waterhouse A.L. Understsnding wine chemistry/ A.L.Waterhouse, G.L. Sacks, D.W. Jeffery. Chichester, West Sussex: John Wiley \& Sons, Inc. 2016. 443 p. https://doi.org/10.1002/9781118730720.ch3.

11. Moreno J., R. Peinado R. Enological Chemistry. Chapter 14. Buffering Capacity of Wines // Academic Press, UK. 2012. P. 223-251. https://doi.org/10.1016/ B978-0-12-388438-1.00014-5.

12. Obreque-Slier E., Espinola - Espinola V., López-Solis R. Wine pH Prevails over Buffering of Human Saliva // J. Agric. Food Chem. 2016. Vol. 64, № 43. P. 81548159. http://doi.org/10.1021/acs.jafc.6b03013.

13. Otsuka K., Totsuka A., Nozu S. et al. Buffer Capacity of Red Wine. Part 1. Fractionation of Buffer-Substance // J. Soc. Brew. 1976. Vol. 71, № 5. P. 398-402. https://doi.org/10.6013/jbrewsocjapan 1915.71.398.

14. Otsuka K. Totsuka A., Iimura Y., Suwa T. Buffer Capacity of Red Wine. Part 2. Source of Buffer Capacity// J. Soc. Brew. 1976. Vol. 71, № 7. P. 545-548. https:// doi.org/10.6013/jbrewsocjapan 1915.71.398.

15. Lambri M. Colangelo D., Dordoni R., De Faveri D.M. The effects of different protein:tannin ratios on the tartrate-holding capacity of wine model solutions // Food research international. 2014. Vol. 62. P. 441-447. http://dx.doi. org/10.1016/j.foodres.2014.03.044

16. Cosme F. Vilela A., Jordão A.M. The role of tartaric acid in grapes and wines (Book Chapter) // Advances in Chemistry Research. 2017. 80(2). P. 347-362. https:/novapublishers.com/shop/advances-in-chemistry-research-volume-40/ (дата обращения: 15.03.2019)

17. Sirromet Wines Pty (Ltd).Wine $\mathrm{pH} \&$ acidity. Concepts and chemistry of $\mathrm{pH}$ organic acids, buffer capacity and wine quality implications of $\mathrm{pH}$. https:// slideplayer.com/slide/8339529/ (дата обращения 22.04.2019).

18. Остроухова Е.В., Пескова И.В., Погорелов Д.Ю. Профиль органических кислот винограда белых сортов, произрастающих в Крыму // Плодоводство и виноградарство Юга России, 2019. № 56 (02). С. 122-132.

Ostroukhova E., Peskova I., Pogorelov D. The organic acids profile of white-berry grapevine cultivars growing in Crimea // Fruit-growing and viticulture of the South of Russia, 2019. № 56 (02). pp. 122-132. (in Russian)

19. Dartiguenave C., Jeandet P., Maujean A. Study of the Contribution of the Major Organic Acids of Wine to the Buffering Capacity of Wine in Model Solutions // Am. J. Enol. Vitic. 2000. Vol. 51. P.352-356. 